\title{
Dealing and sharing: the construction of community in a Pretoria public park
}

\author{
Dennis Edward Webster \\ Department of Anthropology and Archaeology, University of Pretoria, Pretoria, South Africa Email: \\ dnnswbstr@gmail.com
}

This paper describes how a group of men, who are invisible to the state because they possess no formal legal documentation, such as ID books or passports, and do not take part in the formal economy, live in a public park in Gezina, Pretoria. It explores how they negotiate some of the ambiguities of street life and community through acts of sharing and illegal public gambling. While the moral and economic principles organising life in the park are plural, forms of everyday communism predominate. I argue that this predominance allows for a form of community that allows the men living there to navigate their daily uncertainties more easily, and explore the ways in which public gambling functions to maintain the conditions for constructive relations amongst them.

Keywords: community; everyday communism; gambling; public space; reciprocity; sharing; sociality;

\section{Introduction: considering community in the Park of 9}

On a hot February afternoon, after a day of fruitless conversations and anxiety about my ability ever to come to grips with what was happening on the streets of Gezina in Pretoria, I ran into The Great on my way home. He had a newspaper rolled up in his hand, a furtive smile under his peak cap. Sitting on a paint canister, he was guarding cars at his usual spot on the corner of Steve Biko Road and Flowers Street. When I saw him, I approached him with a cigarette and accepted his invitation to sit and talk a while. After some time, The Great and I walked to a park that was located only a block away. I had barely noticed it before. We were greeted by uncomfortable stares and silence. We sat down next to a man tossing a worn box of cards, his greeting as gravelly as the ground on which we sat. When The Great asked me for R 20 in a whisper, I realised how quickly he had taken advantage of my mention in a previous conversation of being interested in studying street life in Gezina to see me as a potential sponsor for his gambling. Since I was in no mood to exaggerate the obvious tension my presence had created in the park, and also aware that I had been given an opportunity to take part in the park's activities, I quickly produced the money and watched how the two men dealt the cards, accumulated and discarded them while splitting and reforming the money in a host of different combinations as it was lost and won.

The Park of 9 lies on the southwest corner of Flowers and Johan Heyns on the southern end of Gezina, Pretoria. Legally, it is owned by the City of Pretoria/Tshwane and run by its municipal officers. The suburb of Gezina lies between two mountain ridges running through Pretoria - the one separating it from Pretoria North and the other linking the affluent southern suburbs of Arcadia, Hatfield, Brooklyn and Waterkloof — and, stretched along Steve Biko Road which is its principle street, is almost directly north of the city centre. The area is a mixture of suburban, semi-industrial and commercial zones, with a vast array of pawnshops, furniture stores, fast food chains, pool halls, street vendors and petrol stations. Gezina is a hub of the automotive trade. From south to north second-hand car dealerships line Steve Biko Road, where I was living during the research. The men who live in the park, however, do not benefit economically from these establishments. Rather, they fashion their own forms of labour and income in the streets of Gezina. Many of them guard cars there. A few of them sell 
cigarettes around the park, while others stand outside the hardware store further down Steve Biko advertising themselves as handymen - painters, plumbers and gardeners. The men use the park to do their laundry, store their belongings and spend their free time.

While the Park of 9 was envisioned as a communal public space for the rate-paying residents of Gezina, the park's use is largely shaped by the suburb's iterant workers and unemployed men who occupy it. About 25 men, all black, live in the park while others drift in and out or conduct their business there. There are, for instance, some men who sell drugs in the park but are not a part of the community there. It is those men who regularly sleep in the park that I discuss in this paper. ${ }^{1}$ Most of these men spend the nights sleeping under blankets, along with their possessions, on the pavement outside of the Turtle and Parrot bottle store a little further down Steve Biko Road. A few of them also sleep underneath a pavilion-like steel-roofed structure in the park itself. The sleeping arrangements are quite stable, and the men usually sleep in the same place every night. The park is where they hang out and socialise, catch up on sleep, cook, clean, eat, drink and share news, stories and jokes. They argue and sometimes fight. They leave in search of work and return after work, or after failed attempts to find work. Uncertainty is the defining social fact of life in the park. This uncertainty takes the form of precarious living conditions, a poor sleeping situation, unreliable formal employment and a distant, but volatile relationship with the state. Most of the men no longer own or have never owned identification documents: this is a hindrance to their chances of engaging in formal economic activity. Indeed, as I will show, the most genuine interactions they have with the state involve attempts to avoid the police when they raid their illicit public gambling, which animates daily life in the park. So a major aim here is to situate and describe this uncertainty, and to examine how the men in the Park of 9 deal with it.

Hanging out with the men in the park was variously informal — watching, discussing, joking and gambling. This informality complimented the more formal interviews I conducted. Through it I came to reflect closely on those subtle gestures between people that are so natural to their relationships that they become almost imperceptible, those acts so repetitive that we tend not to notice them or allocate any real importance to them - sharing a cigarette, small moments of advice or help, teasing. These acts, between the men in the park and between them and me, were the mundane blocks from which significant relationships were built.

In this paper I outline some of the most important dynamics of sociality amongst men living in the Park of 9. I argue that, while not the only grounds for economic relations in the park, forms of "everyday communism" (Graeber 2011, 2014) are predominant and allow the men there to make a community under conditions of uncertainty. I then address why it is that these relations - small acts of sharing and help - are predominant, and how the grounds for that predominance are maintained. To answer these questions, we need to understand the gambling that goes on there. I argue that gambling is one response to the uncertainty that the men feel. In a way they see their own lives as a kind of gambling, and it is the activity in which uncertainty and risk are most visibly engaged with and talked about in the park. I aim to show that gambling, which crucially never involves a "House," functions to redistribute money among the men in the park and maintain the possibility of relations based on this baseline communism. This, in turn, allows the men to construct and continue some form of community, which makes living in the day-to-day uncertainties in the park easier.

\section{The Great: the profligate pretender}

On a balmy February afternoon, I found The Great asleep in the park. He slowly stirred and turned towards me, perhaps smiling at my eager return. He groggily told me that no one had been gambling that afternoon. But after we sat a while talking, a man in leather boots and wide-brimmed leather hat sauntered off the street and towards us on the grass. The Great pushed himself to his feet, "Just wait, here comes The Cowboy. He always wants to gamble." The two men greeted, spoke and laughed together for a few minutes, and then sat down to shuffle a deck of cards, which The Cowboy produced from his jacket pocket. Then they began. I had provided the R 20 with which The Great bet. He told The Cowboy, who was lying casually on his side, that he was teaching me how to play. I lit a cigarette 
each for the three of us and sat back watching. Just then, a young man came from across the park, loudly continuing a conversation he was having there. He crouched between me and The Great, quietly asking something of the latter. Without looking up from the hand he had just been dealt, The Great leaned forward off the large canister he was sitting on. The visitor opened the lid of the canister, rummaged inside, pulled out a tea bag and closed the lid again. He then jogged back across the park, resuming his shouted conversation, as The Great sat down, re-ordered his hand and began to play again.

As the game continued, The Great recalled, "He hit me, here!," slapping the side of his neck ${ }^{2}$ to signify the loss he had suffered at his last encounter with the Cowboy, while he tossed another card onto the ground. The Great told me that no one in the park knows his own real name; people refer to him only by the nicknames he gives himself, including those of well-known soccer players. "The Great," for instance, was the handle of a 1980s player for the Soweto club Moroka Swallows. The Cowboy, now reclining, quietly laughed and warned me to "Be careful of this one," as he took a card from the deck, slowly bending it and then snapping it into his hand, exclaiming the conventional "Ei!" Examining the cards in front of him, he coolly discarded one. It was a winning card for The Great who, with a wry grin, dropped his hand on the floor to show that he had won. He collected his winnings and placed his next bet. The Cowboy, no longer as cheery, pushed himself upright to respond to the bet and shuffle the deck. "You see? You see?," he exclaimed, "Now he's hitting me here, hitting me here!" He also slapped his neck. "This one, he's a criminal." The Great and I chuckled, as the pair began the next hand.

On many walks around Gezina, and during all the hours spent gambling and hanging out in in the park since our first meeting, I listened to The Great's story of his 42-year life, the last four years of which he had lived in the park. Born in Mpumalanga, The Great lived in and around Hectorspruit for most of his life. He was 27 when his mother, with whom he lived after his father's death, passed away. He then left Mpumalanga for Pretoria. His two sisters, both of them married, had also moved away from home. It was they who had taught him how to gamble. They were employed as domestic workers and he would visit them during the day where they worked to play card games. His remaining family felt he was not capable of running his parents' household and gave the responsibility to "some Mozambican man" who, The Great said, was "looking after my daddy's house until I can come back." This homecoming proved difficult, however, with The Great struggling to put together the money that would prove to his family that he could run things. His efforts ranged from working at a supermarket in Garsfontein, fixing truck engines in Pretoria north, gardening at a Silverton home and doing handyman work all around the city. The Great explained his constant job changes with reference to dependability: he felt that none of the jobs he had worked offered any real security of continued income. After spending 11 years roaming the city, never staying in one place for very long (he lived in Mamelodi, Ga-Rankuwa, Shoshanguve, in friends' houses and on the street), he joined a friend one evening at a dice game in the Park of 9. As he started to spend more time and money gambling in the park, The Great slowly got to know the men there. Growing into the life of the park - which has come to be the closest thing to a home for him in Pretoria - involved employing specific devices to navigate this new and potentially dangerous environment. For instance, he never used his real name with the men in the park. Some men went so far as to adapt entire personas (recall The Cowboy). The Great's introduction to the park was "very difficult and dangerous," he said.

He told a story from the beginning of his time there that illustrates how far he went to build relationships of trust with the other men. One evening a dice game was raided by a police van driving by. The Great, who was still new to the area and not yet adept at avoiding such raids, was caught by three officers while trying to get out of the park. They beat him up viciously and jeered at him for smelling of beer, and then asked him who had been the nox $-\operatorname{man}^{3}$ of the game. Knowing that the police were looking to pin the guilt on someone quickly ${ }^{4}$ - indeed the hasty nonchalance of police violence typifies the relationship between the men in the park and the state - The Great admitted to being the nox-man, although he was not. The police threatened him with prison unless he paid over his winnings. 
These were only about R 40 he says, but he paid them over and in so-doing rid the park of police presence for the rest of the evening.

The story of The Great's false confession to the police illustrates how he made the transition from outsider to insider among the men in the park. It is also one example of how relationships there are often formed and negotiated in the context of gambling. In this case, by admitting his part in the dice game, The Great placated the police who were a frequent and often violent source of disruption to life in the park. In this way he proved that he had the interests of the men in the park in mind and could be trusted. I heard Phillias, a man who had lived in the park for some time, laugh and recall on more than one occasion how "stupid" The Great had been to be beaten up that evening. The Great grinned in his turn, but insisted that only after taking the fall for the dice game did the men in the park start to accept him.

I was able to use techniques of my own to blur my position as an outsider at times. Sharing, for example, is a key way for the men themselves to mark social boundaries in the park and it allowed me to bridge the gaps between the park regulars and myself and build some kind of relationship with them. I shared many cigarettes during the course of my research, even with Eric, who had initially been wary and sometimes angry at a white man spending so much time in the park. During the winter when I sported a formidable beard, which he found ridiculous, Eric mocked me for looking like a boer. ${ }^{5}$ But no methodological nuance would have allowed me access to the social realities of the Park of 9 without my relationship with The Great.

By the time I met The Great, he was an authoritative figure in the park. Not long after his false confession to the police, he had found a more regular source of income guarding cars outside a machinery store on the corner of Steve Biko and Flowers. While he admits to having had better paying jobs in the past, he has held onto this one for the last four years. Given the frequency of his job changes before he came to the park and his desire for more economic security, it is curious that The Great stuck it out on a Gezina street corner, guarding cars for less than he made elsewhere. I argue in the following sections that this is related to the community he and others built up as regulars in the park, and the network of support which it allowed.

\section{A sociology of everyday communism: sharing in the Park of 9}

A great deal of what I did in the Park of 9 involved smoking cigarettes. It is only retrospectively that I appreciate what a stroke of luck it was for me, as a fieldworker in the park, to be a smoker. Sharing cigarettes and matches began most of my conversations and some of my relationships with the men in the park. Indeed, my relationship with The Great began with smoking. Later it became a standing joke that I smoked too much. One afternoon he scoffed at me for using my own match to light a cigarette after he had already used a match to light one I had given him — "We save matches here," he said. After that, I rigorously imitated the elaborate sharing practices that surrounded smoking in the park. Matches are always shared, as The Great taught me, by lighting at least two cigarettes with one match. A cigarette is always shared by at least two men and it is uncommon to see someone finish a cigarette alone; the last few drags are always given to someone sitting nearby. I never opened my box of cigarettes without offering them to those around me, who would always accept, and the men in the park, me included, would often buy loose draws ${ }^{6}$ for our companions if we were buying for ourselves. These types of sharing became so habitual that I only realised their frequency when rereading my field notes weeks later. Graeber $(2011,89)$ holds that understanding the moral grounds of human life - and of anthropology - must begin with small things: actions, sentiments and gestures that we would never stop to notice, but that nevertheless saturate everyday sociality.

Re-reading my notes also made me notice how much of social life in the park resulted in, or was prompted by, sharing. The sharing engaged in by smokers could be seen as being universal (Graeber 2011, 97); and it has been observed amongst street people the world over (e.g. Snow and Anderson 1993, 173). Not all sociality is based on sharing cigarettes, nor indeed on sharing, but it is a reliable mechanism for developing sociality. ${ }^{7}$ 
Sharing in the park went further though. For instance, the old paint canisters in which many men kept their clothing, blankets and other personal items were also used to store basic foodstuffs like tea, coffee and sugar. These foodstuffs, although held individually, were shared around the park to the extent that they were almost commonly pooled. Every day I would see men jogging across the park to ask someone for a tea bag or the like. Moreover, on most evenings the men would cook pap (cooked maize flour) and bones ${ }^{8}$ to be shared around a fire for supper. Someone would provide pap from their personal stores, while someone else would buy the packet of bones from a man (whose name I never learnt) who passed through the park every evening selling bones and meat.

These moments of sharing are hard to describe because of their brevity. But the pattern is so frequent and pervasive in the park that they become the most constant characteristic of relationships there. It is most noticeable when the principle of sharing is breached. One afternoon while I was playing cards with The Great, an enraged man approached us, accusing The Great at the top of his lungs of having cheated him. It turned out he thought The Great - who immediately took up an aggressive posture - owed him R 2 for a "loose draw" that he had bought The Great a week before. This was the only conversation I witnessed that grabbed the attention of the entire park, which went eerily quiet. While the man tried to take his $\mathrm{R} 2$ from the money lying between The Great and me (with which we were gambling), Phillias and two other men came from across the park, where they had been starting the evening fire, grabbed him under his arms and pulled him away, warning him that he was out of order.

The man's allegations against The Great and the reaction of everyone in the park towards him show clearly the communistic nature of sharing: to the men, it was astonishing and even insulting that any account should be kept of something like "bumming" a cigarette. And in much the same way, no shared tea bag or cup full of pap was ever tallied or tabbed. When taking accounts seems morally offensive, we are in the presence of what David Graeber has called "baseline communist relations." These must be distinguished from reciprocity. Whatever it might actually be, as explored in the context of functional theory by Alvin Gouldner (1960), and in all of its various shapes, such as those outlined by Marshall Sahlins (1972), reciprocity involves temporary forms of debt. Everyday communism, on the other hand, relies on a kind of "permanent mutual debt" (Graeber 2014, 71, my emphasis), wherein "uncalculated pooling of resources is basic to sociality" (Hart and James 2014, 8, my emphasis). Graeber is concerned with a mundane kind of communism, which he suggests "is the foundation of all human sociability" (2011, 96, original emphasis). That is, all social systems have in them a base of already existing communistic relations, even though they cannot be organised along communistic lines alone. Crucially, he is concerned here with relations that allow for society. As Sahlins (1972) has argued, almost paradigmatically, reciprocity is intimately linked with cultural and kinship systems; that is, certain systems condition the kinds of reciprocity that given social agents can engage in. Reciprocities, in this sense, are because of society. While the reverse may also be true, certain cultural frameworks are central in allowing for certain kinds of reciprocity. These sorts of broader frameworks are absent under the conditions of severe uncertainty in the Park of 9 and amongst the strangers who live there. And it is here where the distinction between reciprocity - as a form of exchange - and everyday communism becomes important.

Everyday communism is not a novel insight. Graeber leans heavily on Marcel Mauss's "system of total prestations." Indeed, already in the first half of the twentieth century Mauss was calling the kind of "total reciprocity" in these systems "communism with an individual, social, and familial base" ([1947] 2007, 104-105, my emphasis). The more competitive "potlatch" dominated Mauss's famous essay on gifts and his argument about their use in establishing social debt or obligations, and therefore social relations ([1950] 2002). But Mauss starts with the "total prestation" or "total services," wherein groups strange to each other are faced with the prospect either of violence or of giving everything to each other in order to avoid exactly that violence, thus establishing a permanent social debt between themselves: "they [the gifts] are strictly compulsory, on pain of private or public warfare" (Mauss [1950] 2002, 7). This is very different from the antagonism that characterises the potlatch, where gift 
giving is a matter of accruing social status that may be useful at a later stage for a given group. Gift giving in a system of total prestations (which, according to Mauss, precedes the potlatch in time) establishes a relationship wherein each group has equal rights to call on the other. "Everyday communism" is conceptually indebted to systems of total prestations for the permanence implied by the nature of the gifts given in these systems - gifts of an order that can never be repaid. The assumptions of permanence demanded by relations of everyday communism similarly allow for some form of social bond, or in the case of the park, community: baseline communist relations can exist, and predominate, only insofar as the members of a community act as though that community will endure, even if they know that may not be the case (Graeber 2011, 2014).

Graeber is also indebted to Mauss for his search for universal principles - principles that collectively constitute the social possibilities already present, even in embryonic form, in any society. It is very important to note that everyday communism was not the only principle shaping sociality amongst the men in the park. My central concern, however, is why it was the principle that predominated amongst the regular men there. In a context of such uncertainty, and often illegality, it is important to understand why relations are not marked by greater degrees of suspicion or even violence. The significance of social relations that are maintained through acts of help or support in shared spaces of socio-economic difficulty cannot be overstated. Philippe Bourgois' work in East Harlem for instance, while in an entirely different context, deals with similar uncertainty and illegality. He notes the ways in which drug dealers there establish crews through acts of what he calls "generosity" in order to provide "a stabilizing social atmosphere ... to counterbalance the anxiety that constantly threatens to disable" (Bourgois 2003, 107) the ability to lead daily life without constant incursions of violence.

The daily activities of the men in the park are not shaped by the sort of market relations or interactions with state bureaucracy that are characteristic of contemporary city life - they pay no tax, mortgage or insurance, they have no bank accounts, they do not qualify for social grants, their purchases at stores are limited to essential foodstuffs when they can afford them, and so on. Social relationships are thus less entangled with formal institutions. The communism suggested by Graeber, therefore, becomes particularly evident. Moreover, the uncertainty that characterises life in the park calls for greater innovation when approaching day-to-day situations. Outcomes are not as predictable as they may be in a formal economic routine (Hart 2010, 142) and so the men are forced to approach them with constant invention. Ironically, baseline communism is often very efficient in these contexts where mainstream economics would have us believe quite the opposite. This is part of the reason why everyday communism is predominant in the sociality of the park. In a context of acute uncertainty, the men in the park, who are from vastly different cultural, geographical, and even national backgrounds, become something more like neighbours or even brothers by sharing in the way they do.

In the earlier stages of my research, the only kind of relationship I could initiate was as a donor to the men begging from me in the park; cigarettes were given rather than shared. This kind of giving is transient and the pleasantries are superficial. There is no reason for the two parties to see each other again. As I spent more time in the park, however, this type of interaction was slowly replaced by one of sharing. The relationships were no longer one way. I was now offered as many cigarettes as I offered; I sat and shared in meals and beer around the fire. In this way my relations with the men in the park shifted from being a blatant outsider at first to something less easy to define but more intimately involved through sharing.

There were often men, and sometimes women, who only spent the occasional afternoon there and others whom I encountered once only. These passers-by usually visited the park to catch up on sleep on the grass banks or to watch the gambling and sometimes join in a game. I never once saw a regular share anything with these passers-by, nor did any of them sit around the fire taking part in casual conversation. The drug dealers in the park also never shared with the men I hung out with; rather they smoked their own cigarettes, drank their own beer and sat in their own corner of the park. The park community thus regulated itself, internally and informally - that is, through tacit customs, conventions and regulations rather than state-made laws - and regulation was marked by who took 
part in the baseline communist aspects of sociality.

The Great once said to me that he would never make a friend in the park, because you can never truly trust someone fighting for his own economic survival; yet he often expressed familial sentiments when referring to the men in the park. For instance, my landlord, who was suspicious of the amount of time I spent in such an unsavoury public space, once asked The Great what I was doing there. He seemed to think that I had a drug problem. The Great laughed about "that fat white man" and gave me a guarantee: "We [the men in the park] will never tell. We stay together and they [anyone not intimately involved in the goings on of the park] must never know anything." Why is it in a situation where conditions are so uncertain that a baseline communist ethic, amongst the plural economic principles shaping relations, prevails? And how is this ethic maintained?

\section{The "merry-go-round": gambling in the Park of 9}

The Great said of gambling that money is "like a merry-go-round; it always comes and always goes." And if sharing is the core of relationships in the Park of 9, the most popular activity there is gambling. The most common image there is of a circle of men sitting on paint canisters or spread out on the grass around a game of cards. Three different gambling games are played in the park: two card games, 7-card and 13-card, and dice. The card games, at which I eventually became quite proficient, are more relaxed and conversational. Life outside the games is discussed while they are being played - soccer results from the previous weekend, retelling and joking about what happened over the weekend, complaints about the government and especially the police, stories of work or failed attempts at getting work, and so on. I never witnessed any argument or accusation of cheating in a card game. Rather, men teasingly recall times when they had been "hit" in a card game and are even willing to show their hands to other players and spectators and receive advice on how to play them.

A winning hand ("trick") in 7-card consists of eight cards (including the pick-up), of which six must be two sets of three which are either a run in a suit (e.g. 5, 6, 7 of clubs) ${ }^{9}$ or three of a kind (i.e. 3 jacks). Two players are dealt seven cards and then pick up (either from the deck or the card that the other player discards) and discard one card per turn until a winning hand is achieved. Each player bets R 10 per hand or R 5 if a player does not have enough money with him to bet R 10 . All bets and exchanges take place between the two players. 13-card is a very similar game, where a winning hand consists of 14 cards, of which twelve must be three sets of four, which are either a run in a suit or four of a kind. Each player is dealt thirteen cards.

Dice, on the other hand, is a high stakes game, which I never had the nerve to play, and is characterised by higher wins and losses, and a constant threat of violence: I have often seen men cut and bloody as a result of brawls around a dice board. These fights are more often than not caused by accusations of cheating. ${ }^{10}$ Such is its complexity and the speed of play that even by the end of my time in the park I had not developed a nuanced understanding of dice. Conventionally it is played on a large carton board, roughly a metre square. The surface, which allows for fairer rolling, is crucial to the maintenance of order around the gambling. There are a varying number of players (I have seen dice games between up to four players) who bet increasing amounts of money as the game progresses (the highest bets were R 150, but I have heard tell of R 400 bets). Each man has his turn to roll the two dice and bet money on their own rolls as well as on those of other players. The different combinations of dice rolled determine the outcome of the betting and the game. They may allow a roller to roll again, force him to pass the dice on to the next player, win him the money that has been bet or win the money bet for one of the non-rolling players. The bets are overseen by a nox-man, who also provides the dice for the game and is meant to ensure that no cheating takes place. Bets are called and agreed on through the nox-man: he oversees the raising of bets and confirms that the players are happy with them. The high stakes often attract players from outside the park and more attention from police. As a result, some of the themes that I address here - the relationship between the men in the park and the state, the nature of the community of men in the park and the dynamic between them and those from outside - play out more visibly in the context of dice games than anywhere else. 


\section{Dice by candlelight}

After spending the lunchtime hours playing 13-card with The Great, Madala, Rasta and Phillias, I was invited by The Great to come and watch a dice game in the park later that afternoon. I entered the park, as I usually did, by the vendor stall on Flower Street and, after exchanging the customary gruff greeting with Big Mos (one of three marijuana dealers in the park, who commanded a good deal of authority), I realised that the game had already begun behind the services centre (a $3 \mathrm{~m}$ square walled structure housing the park's irrigation systems and the like) on the western end of the park. The sounds of activity around the dice board became apparent as I drew nearer.

On arrival, I drew a cigarette and offered one to Rasta who was watching the game, while The Great, without looking at me, accepted another, which I slid over his shoulder. I had not met many of the men playing and watching before and was greeted by a series of sceptical and silent stares in the first few moments, something that made Rasta chuckle quietly alongside me. Lighting my cigarette I stood back with him and some others watching the game. A quick glance at the numerous R 100 notes exchanging hands across the board and the energy of the ten or so men surrounding the five intently crouched over the clattering dice confirmed the high stakes. It was entirely unlike the more deliberate, conversationalist card games I had become used to. The Great was having a bad night and his pleading with the dice as they rolled across the board, "Sweetheart! Come my sweetheart, please my baby!" was often followed by a frustrated, "Agh shit man! Shit!"

After watching for some time I met a young man, Xolani, who like me had been patrolling the edge of the game. Being similar in age and both from the Eastern Cape, conversation with Xolani was easy and, after realising we were both very new to the gambling in the park, we discussed its meaning and purpose before sharing stories about various places in the Eastern Cape. A shrill whistle suddenly interrupted us, splitting the air and stifling the drone around the dice board. In the time it took me to realise that the whistle had come from Eric perched on the fence at the bottom of the park, a position I had imagined was casual, the entire game disappeared in front of me and all the men, gathering their particulars quickly, were agitatedly glancing towards Flowers Street as they began to jog gently towards the opposite end of the park. Recalling that dice playing was illegal, I was the last to realise that a police van had parked on the Flower Street sidewalk.

All sense of anthropology and fieldwork immediately forgotten, I caught up with The Great who was breathing heavily and in quite a panic near the end of the park, but still laughing at me. From our position in the thick shadows provided by the wall that runs the length of the park, separating it from the apartments and businesses on Voortrekker Road, we watched the police. The Great had learnt a lot about their movements since his first experience and seemed confident that they posed no real threat. While I fidgeted behind him, an adrenaline rush told me that confidence at a time like this would be reckless. The van lingered for a while at the bottom of the park and then left. After a short wait, the men re-established their game. The Great was by now fed up with his losses and I went with him to investigate whether the police had truly left and to fetch some candles for the dice board, as the dark was setting in. Along with many of the personal possessions of the men sleeping in the park, the candles are kept in the roof of the pavilion-like structure meant to provide shade in the play park located at the southern end. Our time away from the game was dominated by The Great's lamentations over his losses. "They're eating me tonight. These guys, they're stealing from me, man. I don't know how, I can't see them, but I'm telling you they're stealing from me."

On re-joining the game, which had already re-established its frantic tempo, we lit and placed some candles on the board, and stood back to join the onlookers in conversation and commentary. The Great teasingly suggested that the next time I came to a dice game it should be at night, next to a fire and by candlelight: "Now it's not dangerous, now we just play. We eat, we eat, we eat!" I listened intently to the men crooning to their dice before they clattered them across the board, "Come now my love, my sweetheart," clicking their fingers every time they did so and then energetically exclaiming the numbers they hoped to roll, "Eish! 3210!" (a well-known model of Nokia cell phone, and reference to a roll of 3 and 2); "Ei! Four one!" Comments from player to player concerning each other's play were 
also common: “Ja, jy, jy speel soos Bheki Cele ${ }^{11}$ nou!” [Yes, you're playing like Bheki Cele now]. The game reached a crescendo when a young player who was doing very well - I had not seen him in the park before that evening — stood up in boisterous exhortation, "My money is my money! That is my money!" The same player, after a losing streak some ten minutes later, stood up in a fluster, muttering to himself about being robbed, and left the group to go and sit alone underneath a nearby tree for a while. There he spoke to himself and gestured for a few minutes before returning to take his place at the board.

This short account illustrates some key aspects of the dynamics between the men in the park and specifically how those dynamics play out in the context of gambling. A key component of taking a risk is to expose oneself to unforeseen outcomes. As a result, the theme of exposure and concealment is crucial to a discussion of how the men gamble in the Park of 9. Dice is different from the card betting in the park in that more care is taken to keep the game from the view of the police. I was unaware of the extent of this care until I reflected on Eric's strategic but casual position at the bottom of the park during the evening just described, from where he could quickly warn the players of any police presence. Indeed, on The Great's advice, I only attended night-time dice games since that skittish jolt in the face of the gomogomo [police].

Despite its heightened concealment, dice is the most eagerly watched of the games played in the park. And so, concealed from the greater park, but exposed to a compact, select and eager audience, dice remains and even exemplifies a site where complex relationships between insider and outsider in the park are negotiated and appropriated towards various ends. Spectators are considered by those gambling as neither involved nor fully aware of what is going on. The loosely established physical boundaries between crouching gambler and standing or walking observer highlight this, together with the cool reception I received and the minimal interaction between those gambling and those watching. The audience are recipients of the players' performance, as when the young man stood up and exclaimed at large about his money. Players and audience are aware of the performative risks, in particular the risk of personal embarrassment.

The content of the performances themselves is also interesting. The structure of the game and its performance are open-ended enough to allow the players to bring in elements from their lives outside. These elements are as varied as the nationalities and ethnicities of men in the park, involving contemporary politics and modern technologies. ${ }^{12}$ Indeed, constant feminisation of the dice as they were rolled was the closest thing to an explicit mention of women I heard the men make. Aside from a few conversations with The Great, when he said that he would never have a wife, only a "cherrie,"13 and the few and intermittent visits by women to the park, the presence or mention of women there was very limited. Considering that most of the men were homeless, slept outside the local liquor store or in the park itself, and spent most of their days hanging out or working informally, it is likely that the irregular presence of women in their lives extended beyond my observations.

While gambling in the park involved material stakes — the risk of losing money - the simultaneous social stakes made the dice board, and to a less palpable extent the circles around card games, into locations that provided insight into how the men in the park confronted and made sense of their day-to-day existence. By social stakes I mean the performative risks - the animated rolling of the dice, the various verbal expressions, how men deal with loss or success in the face of the other players and those watching, and so on - together with the obvious legal risks of gambling. The young man who left the game to bemoan his loss alone was aware that to interrupt the game would be to run the risk of upsetting the order - performatively constructed and maintained — and risk accusations and violence.

Performative gambling as a way of symbolically condensing everyday life and making sense of it or of commenting on it is of course not limited to the Park of 9 (see for instance Feige \& Ben-Ari [1991], Holbraad [2010], Malaby [2003]). It does, however, allow me to address why gambling is important in the park. Any gambler must ultimately confront the idea of his own eventual loss (if it were truly believed that gambling yielded net winnings, it would be a far more celebrated and engaged 
form of economic activity), which adds to gambling's significance in this context.

All forms of gambling at the Park of 9 do not rely on a "House," but rather take place directly between the gamblers themselves. Also, over time, the winnings and losses of any player, with some exceptions, tend to even out. While I had many conversations around card games of big winnings or losses, they seemed always to have happened outside of the park. This evening-out of wins and losses is revealed by how the card games in the park work. While some skill, patience and awareness of which cards have been drawn and played are required for a successful performance, the games are ultimately based on 50/50 chances. They take place between two players, one of which loses a given trick while the other wins it. In any game, one player may lose or win more tricks than the other, but the even chances translate into a general 50/50 ratio over time.

This situation is captured in The Great's comment about gambling in the park as a "merry- goround": coming and going. Considering that the money used to gamble in the park is made either from gambling elsewhere or day-to-day employment in its various forms, the games can be seen as a process of redistributing money among the men in the park. This redistribution adopts specifically nonhierarchical forms, as evidenced by the absence of a House or Bank from any of the gambling in the park (which, as any statistician will tell you, always wins). Madala told me laughingly, "We have gambling. Every day we have gambling. Sometimes also we have work. So we make money and we gamble with that money; this is the way it is." And, while The Great constantly referred to work as an essential source of income, he always maintained that what he earned guarding cars he would gamble, describing gambling as a source of "sure money" and "fast money."

Graeber points out the ease with which, in the plural economic principles that constitute a given social reality, communistic relations can slip into relations of hierarchy. Under the conditions of uncertainty that characterise these men's daily lives, such a shift is very easy. It is noteworthy that drug dealers in the park never join any gambling activity. Of all the park's denizens, they consistently make the most money, offering something in constant demand not only by the men in the park, but also by an array of buyers from the surrounding area. They thus occupy an economically dominant position relative to the men I worked with - their relationship is decidedly hierarchical. Consequently, they do not engage with the everyday sharing aspect of sociality of the park, nor in any of the gambling which I suggest allows for the predominance of that sharing. This adds up to a sort of economic hierarchy, as when regulars act as lookouts for the drug dealers for example; and it would interfere with the communistic ethos of the rest of the park.

It is also revealing that, while all the regulars acknowledge drug dealing as the easiest way to make money, the great majority of them choose not to deal themselves. Not having spent a great deal of time with the drug dealers in the park, it is difficult to say how free the regulars are to make this decision for themselves, and how strongly such a decision would be influenced by territorial concerns. Nevertheless, it remains illustrative that the men value the drug dealing in a certain way. They acknowledge it as the easiest way to make good money, yet they demean it for its social implications. When out of earshot, Rasta, a participant during the research, would often ridicule the drug dealers for not having any friends. Rather, the men regular to the park took part in the everyday sociability of life in the park - working and earning money where they could, socialising, eating, cleaning and hanging out in the park (all of which occupations involve sharing between the men) — and gambling of course. So gambling in the park, as a non-hierarchical process with redistributive results, can be seen as the practice or structure through which the pre-conditions of everyday communistic relations are maintained under circumstances of extreme uncertainty. Were the men living in the park left to fend for themselves, economically speaking, they would face an even greater battle for survival on the street. I often sat with The Great when he had earned a pitiful R 100 from guarding cars for a week. Gambling in the park, however, allowed the men to distribute, more or less equally, the money they made there and whatever was brought in from outside. 


\section{Conclusion}

As in any society, economic relations in the Park of 9 are plural. My focus here has been selective however. At the centre of my enquiry have been two questions: How is it that a group of strangers are able to construct a form of community under the conditions of uncertainty that characterise life in the Park? And why is it that forms of sharing are the predominant form of sociality there? It is my contention that the two are intimately linked. Acts of baseline communism, unlike forms of exchange and reciprocity, rely on relations that assume permanence (Graeber 2011, 2014). The predominance of sharing in the park - glimpses of which I have given here - allows men living in the park to become neighbours. These relationships are some of the most efficient means of handling the varying uncertainty of daily life in the park. The three principle model which David Graeber outlines, and to which I have appealed, acknowledges the plurality of economic relations, the predominance of certain kinds of relations in given contexts, and even the tendency of certain kinds of relations to slip into other kinds of relations. Being a general model, however, it does not go far enough to account for specific predominances, or why relationships may or may not slip in certain situations. The conditions that allow for baseline communist relations in a park characterised by uncertainty and adversity centre on another important aspect of the economic plurality there: gambling. Seeing that no House or Bank exists in the park, gambling takes on redistributive functions. The gambling therefore acts to shape conditions that allow for predominantly baseline communist relations.

\section{Notes}

1. For the purposes of this research, I could not keep track of the men who moved in and out of the park.

2. Being "hit" is to lose money while gambling, and is always expressed by the men in the park by energetically slapping the side of their neck.

3. The nox-man provides the dice for a game and oversees the bets called by the players. While none of the money goes directly through him, his function is to keep order in the game. He handles accusations of cheating and the like and sees that it does not erupt into violence, a common feature of dice games (see below).

4. The raids in the park - both those I witnessed or was a part of and those I heard of - never resulted in serious legal action. Rather, they usually ended in verbal and physical harassment of the men in the park and the payment of a bribe to the police.

5. The men in the park use boer not to refer to farmers (its direct translation), but rather to white Afrikaners in general and to those with right-wing tendencies in particular.

6. "Loose draws" are single cigarettes, usually bought from men walking around the park with a carton or from the vendor on Flowers Street.

7. Cigarettes are the most constant marker of interactions in the park. They never made there the radical evolution in function from commodity to currency that Radford (1945) witnessed in Second World War POW camps. But we may note that in the park, too, daily life was constructed under oppressive conditions of material scarcity and vulnerability. Reed $(2011,25)$ also noted the importance of sharing cigarettes in shaping the ambiguous and aggressive relations to the state of inmates in a Papua New Guinea prison, where they are used to establish and mark associations and identities.

8. This is an inexpensive and filling meal consisting of a cooked bag of stewing bones with chunks of meat, eaten with pap.

9. In the park clubs are called "currinan," diamonds are called "dice," and spades are called "scope."

10. The accusations I witnessed varied from men playing with tampered dice to men playing with the aid of witchcraft and muti [traditional medicine].

11. This refers to South Africa's police commissioner from 2009-2011, Bheki Cele, who was investigated for official spending irregularities. His name is used to suggest that someone's playing looks dodgy.

12. The men in the park often identify each other's ethnic and national differences through gambling, and I often heard stories of how "that Zulu gambler" had "hit" someone, or how risky it is to play against Zimbabwean dice players. Also political references are not limited to Bheki Cele, or technological references to the Nokia 3210.

13. A "cherrie" can be loosely understood as a girlfriend. Such a relationship does not, however, involve strict sexual commitments or loyalty. 


\section{References}

Bourgois, P. 2003. In Search of Respect: Selling Crack in El Barrio. Cambridge: Cambridge University. Feige, M., and E. Ben-Ari. 1991. "Card Games and an Israeli Army Unit: An Interpretive Case Study."

Armed Forces and Society 17 (3): 429-448.

Gouldner, A. 1960. "The Norm of Reciprocity: A Preliminary Statement." American Sociological Review 25: 161-178.

Graeber, D. 2011. Debt: The First 5000 Years. New York: Melville House.

Graeber, D. 2014. "On the Moral Grounds of Economic Relations: A Maussian Approach." Journal of Classical Sociology 14 (1): 65-77.

Hart, K. 2010. "Informal Economy." In The Human Economy: A Citizen's Guide, edited by K. Hart, J.-L. Laville and A.D. Cattani, 142-153. Cambridge: Polity Press.

Hart, K. and W. James. 2014. "Marcel Mauss: A Living Inspiration.” Journal of Classical Sociology 14 (1): 3-10.

Holbraad, M. 2010. "The Whole Beyond Holism: Gambling, Divination and Ethnography in Cuba." In Experiments in Holism: Theory and Practice in Contemporary Anthropology, edited by T. Otto and N. Bubandt, 67-85. Chichester: Wiley-Blackwell.

Malaby, T.M. 2003. Gambling Life: Dealing in Contingency in a Greek City. Urbana: University of Illinois Press.

Mauss, M. (1947) 2007. Manual of Ethnography. Translated by D. Lussier, edited and introduced by N.J. Allen. New York: Durkheim Press and Oxford: Berghahn Books.

Mauss, M. (1950) 2002. The Gift: The Form and Reason for Exchange in Archaic Societies. London: Routledge.

Radford, R.A. 1945. "The Economic Organisation of a P.O.W. Camp.” Economica 12 (48): 189-201.

Reed, A. 2011. "Number-One Enemy: Police, Violence and the Location of Adversaries in a Papa New Guinea Prison." Oceania 81 (1): 22-35.

Sahlins, M. 1972. Stone Age Economics. Chicago: Aldine-Atherton.

Snow, D.A., and L. Anderson. 1993. Down on their Luck: A Study of Homeless Street People. Berkeley: University of California Press. 